\title{
Pedagogické časopisy: jejich využívání jako informačních zdrojů
}

\author{
Jan Průcha \\ nezávislý expert
}

V české pedagogické komunitě je přisuzována odborným časopisům významná role. Kromě jiných účelů - především jako nástroj prezentace a šíření vědeckých poznatků - jsou časopisy považovány za důležitý zdroj informací pro rozvoj pedagogické vědy. Běžně se soudí, že české pedagogické časopisy jsou využívány autory statí a výzkumných sdělení, kteří je citují, tj. odkazují na publikované práce vlastní nebo jiných autorů. Tato role odborných časopisů se v posledních letech stala předmětem různých hodnocení v řadách českých pedagogů. Poprvé se tak stalo na panelové diskusi za účasti předsedů redakčních rad nejdůležitějších českých pedagogických časopisů v rámci XVIII. celostátní konference ČAPV (2010) v Liberci. Přehled o českých pedagogických časopisech zařazených do Seznamu recenzovaných neimpaktovaných časopisů vydávaných v ČR a o kritériích pro zařazení podal Mareš (2010). 0 diskusích k postavení a roli českých pedagogických časopisů informovali Mareš a Honsnejmanová (2011).

Zájem o dobré fungování a kvalitu českých pedagogických časopisů tedy v pedagogické komunitě existuje a je zcela oprávněný. V souvislosti s tím vzniká otázka, jaké je reálné postavení časopisů jakožto informačních zdrojü, které využívají čeští autoři publikující své práce. Můžeme se tedy ptát: Jak mnoho čeští pedagogové odkazují při publikování svých prací na pedagogické časopisy? Které časopisy to jsou? K ujasnění této otázky jsem provedl citační analýzu, jejíž popis a výsledky jsou zde představeny.

\section{1 Účel analýzy}

Účelem analýzy bylo prokázat (na níže popsaném souboru citací) některé základní charakteristiky využívání českých a zahraničních časopisů českými pedagogy. Východiskem je předpoklad, že autorem uváděný seznam literatury u každého časopiseckého článku (stati, výzkumné zprávy) reprezentuje ty publikace, z nichž autor fakticky čerpá, o něž se opírá, s nimiž polemizuje apod. - tedy je k určitým informačním účelủm využívá. K objasnění tohoto využívání jsem formuloval následující otázky, se specifickým zaměřením na hlavní české pedagogické časopisy: 
- Jaký podíl představují časopisy ve srovnání s podílem knižních publikací v souboru bibliografických údajů uváděných českými autory statí?

- Jaký podíl v souboru bibliografických údajů tvoří jednak české časopisy, jednak zahraniční časopisy?

- Jaké podíly v souboru bibliografických údajů tvoří citace odkazující na každý ze čtyř analyzovaných klíčových časopisů (Pedagogika, Pedagogická orientace, Studia paedagogica, Orbis scholae)?

- Existují mezi těmito analyzovanými časopisy nějaké společné vzorce využívání informačních zdrojů nebo se projevují spíše výrazné odlišnosti?

- Je celkově současné využívání časopisů jako informačních zdrojů českými pedagogy podobné nebo odlišné ve srovnání se staršími nálezy citačních analýz?

\section{Citační analýza v souboru čtyř klíčových pedagogických časopisů}

\subsection{Charakteristika souboru}

V České republice je publikováno 18 primárně pedagogických časopisů a 15 sekundárně pedagogických časopisů (podle Seznamu recenzovaných neimpaktovaných časopisů - viz Mareš, 2010). Mezi primárně pedagogickými časopisy jsou čtyři, které se ve vědecké komunitě považují za nejdůležitější. Jsou to: Pedagogika, Pedagogická orientace, Orbis scholae, Studia paedagogica. Tyto čtyři časopisy jsem zvolil pro citační analýzu. ${ }^{1}$

Konkrétní soubor tvoří celkově 8906 bibliografických údajů citovaných v literatuře statí a výzkumných sdělení, jež byly publikovány v uvedených časopisech. Soubor má reprezentovat současný stav, proto byly shromážděny bibliografické údaje vždy za poslední čtyři ročníky (2010-2013) pro každý časopis. Rozsah dílčích souborů pro jednotlivé časopisy je ovšem rozdílný:

\footnotetext{
Volba těchto čtyř časopisů je dána hlavně tím, že jde o periodika zaměřená jak na teoretická, tak na výzkumná témata pedagogické vědy a že jsou to klasické tištěné časopisy celostátního dosahu. Nebylo zařazeno e-Pedagogium, které poskytuje publikační možnosti hlavně pracovníkům olomoucké pedagogické fakulty, ani některé časopisy v oblasti oborových didaktik (např. Biologie - Chemie - Zeměpis, Hudební výchova, Výtvarná výchova aj.).
} 
Pedagogická orientace - 2901 citací v 91 statích; Pedagogika - 2449 citací v 89 statích; Orbis scholae - 2076 citací v 61 statích; Studia paedagogica 1480 citací v 50 statích.

Odlišné počty citací jsou způsobovány různou periodicitou časopisů: Pouze Pedagogika vycházela v daném období standardně ve čtyřech číslech ročně, kdežto Pedagogická orientace je od ročníku 2013 publikována v 6 číslech ročně, Studia paedagogica do roku 2013 ve dvou číslech ročně, poté ve čtyřech číslech, Orbis scholae vycházel ve třech číslech ročně.

Do souboru citacíjsou zahrnuty pouze ty bibliografickéúdaje, kteréjsou uváděny ve statích českých autorů, nikoliv autorů slovenských a jiných zahraničních.

\subsection{Tř́dění údajů}

- Z Z jednotlivých statí všech čtyř časopisů byly shromážděné bibliografické údaje tř́́děny na citace odkazující souhrnně jednak k časopisům, jednak ke knižním publikacím (monografie, sborníky, dizertace a jiné neperiodické práce).

- Časopisecké citace byly tř́děny na skupiny českých časopisů a zahraničních časopisů (včetně slovenských).

- České časopisecké citace byly dále tříděny jednak na ty, které odkazují k některému ze čtyř klíčových časopisů, jednak na ty, které odkazují na jiné české časopisy (i nepedagogické, např. psychologické, sociologické).

Toto třídění tedy umožňuje zjistit, zda a do jaké míry je každý ze čtyř klíčových časopisů zároveň informačním zdrojem využívaným autory. Nebyly odlišeny klasické bibliografické údaje od údajů vztahujících se k elektronickým publikacím (těch je v celkovém souboru méně než $5 \%$ ).

\section{Výsledky citační analýzy}

\subsection{Poměr časopiseckých citací a knižních citací}

Základní zjištění se týká toho, jaké jsou podíly časopiseckých citací a knižních citací. Citují se více časopisy, nebo knihy a jiné neperiodické práce, nebo je jejich poměr vyrovnaný? 
V celkovém souboru 8906 bibliografických údajů byla zjištěna výrazná převaha knižních citací nad počtem časopiseckých citací. Jak dokládá tabulka 1, tento poměr se projevuje i ve všech čtyřech klíčových časopisech. ${ }^{2}$

Tabulka 1

Poměr časopiseckých citací a knižních citací v souboru a podsouborech

\begin{tabular}{lcc}
\hline Soubory & Podíl časopiseckých citací & Podíl knižních citací \\
\hline $\begin{array}{l}\text { Celkový soubor } \\
(\mathrm{N}=8 \text { 906) }\end{array}$ & $24,5 \%$ & $75,5 \%$ \\
$\begin{array}{l}\text { Pedagogická orientace } \\
(\mathrm{N}=2 \text { 901) }\end{array}$ & $24,2 \%$ & $75,8 \%$ \\
Pedagogika & $29,2 \%$ & $70,8 \%$ \\
$(\mathrm{~N}=2449)$ & & \\
Orbis scholae & $23,0 \%$ & $77,0 \%$ \\
$(\mathrm{~N}=2$ 076) & & $62,9 \%$ \\
Studia paedagogica & $37,1 \%$ & \\
$(\mathrm{~N}=1480)$ & & \\
\hline
\end{tabular}

Jistě může být překvapující relativně nízký podíl časopiseckých citací ve všech čtyřech časopisech. Jak vysvětluji níže v části 4 , je to zřejmě jedna z prríznačných vlastností pedagogiky, pokud jde o využívání informačních zdrojů, na rozdíl od některých jiných věd.

\subsection{Poměr českých a zahraničních časopiseckých citací}

Když analyzujeme samotné časopisecké citace, jeví se jako důležitá charakteristika to, jak jsou využívány české časopisy ve srovnání se zahraničními časopisy jako informační zdroje. Data k této charakteristice jsou obsažena $\mathrm{v}$ tabulce 2 .

Data dokládají jednoznačnou převahu citovaných zahraničních časopisů nad citovanými českými časopisy, a to jak v celkovém souboru citací, tak v souborech citací v jednotlivých klíčových časopisech. Jak je patrné, čeští pedagogové se dnes výrazně orientují na zahraniční časopisy - pokud využívají časopisy jako informační zdroje. Jsou to ve více než $90 \%$ časopisy publikované v angličtině, zřídka i periodika německá a francouzská a ojediněle také slovenský elektronický časopis Pedagogika.sk.

2 V tabulce 1 a ve všech následujících tabulkách řadím časopisy podle velikosti př́íslušných souborů citací. Údaje v tabulkách jsou zaokrouhleny na jedno desetinné místo. 
Tabulka 2

Poměr citovaných českých časopisů a zahraničních časopisů

\begin{tabular}{lcc}
\hline Soubory & Citace českých časopisů & Citace zahraničních časopisů \\
\hline $\begin{array}{l}\text { Celkový soubor } \\
\text { citovaných časopisů }\end{array}$ & $30,4 \%$ & $69,6 \%$ \\
$(\mathrm{~N}=2443)$ & & \\
Pedagogika & $27,9 \%$ & $72,1 \%$ \\
$(\mathrm{~N}=716)$ & & $63,6 \%$ \\
Pedagogická orientace & $36,4 \%$ & $70,0 \%$ \\
$(\mathrm{~N}=700)$ & $30,0 \%$ & \\
Studia paedagogica & & $74,1 \%$ \\
$(\mathrm{~N}=548)$ & $25,9 \%$ & \\
Orbis scholae & & \\
$(\mathrm{N}=479)$ & & \\
\hline
\end{tabular}

V př́ípadě zahraničních časopisů jsou to převážně mezinárodní pedagogické časopisy, ale také psychologické, sociologické, medicínské, etnologické, historické, psycholingvistické a jiné časopisy. Paleta citovaných zahraničních časopisů je velmi široká a pestrá. Mezi nejčastěji citované patří zejména Educational Researcher, Journal of Educational Psychology, Review of Educational Research, Sociology of Education, Teaching and Teacher Education aj. Ojediněle se mezi citovanými zahraničními časopisy objevují kuriozity, tj. časopisy u nás zcela neznámé jako např. Anthrozoös, Australian Journal of Outdoor Education, Kentucky Journal of Communication, International Journal of Mental Health Nursing aj.

\subsection{Citovanost čtyř klíčových časopisů}

Fakt, že zmíněné čtyři časopisy (Pedagogika, Pedagogická orientace, Studia paedagogica, Orbis scholae) jsou všeobecně považovány za klíčové pro českou pedagogickou vědu, vede samozřejmě k požadavku objasnit, jaká je reálná intenzita jejich citovanosti. Mohlo by se tedy předpokládat, že tato citovanost je vysoká, odpovídající významnosti těchto časopisů.

Tento předpoklad lze rozdělit podle dvou aspektů. Je možno zjišt'ovat:

1. jaká je celková citovanost těchto klíčových časopisů mezi všemi českými citovanými časopisy; 
2. jaká je citovanost každého jednotlivého klíčového časopisu ve srovnání s ostatními klíčovými časopisy.

K tomuto účelu byl vypočten index citovanosti pro klíčové časopisy celkově. Hodnoty indexu udávají, jak velký je podíl jejich citovanosti. K prvnímu aspektu činí hodnota $I_{\text {cit }}=68,3$. Toto číslo vyjadřuje, že klíčové časopisy celkem zaujímají zhruba $2 / 3$ počtu všech citovaných českých časopisů.

K druhému aspektu jsou vypočteny hodnoty indexu citovanosti pro jednotlivé klíčové časopisy. Hodnoty udávají, jak velký je podíl citací určitého klíčového časopisu v celkovém počtu citací českých časopisů. Př́slušné hodnoty jsou uvedeny $\mathrm{v}$ tabulce 3 .

Tabulka 3

Citovanost jednotlivých klíčových časopisů

\begin{tabular}{lcc}
\hline Časopis & Počet citací & $\mathrm{I}_{\text {cit }}$ \\
\hline Pedagogika & 256 & 34,4 \\
Orbis scholae & 94 & 12,6 \\
Pedagogická orientace & 88 & 11,8 \\
Studia paedagogica & 70 & 9,4 \\
\hline
\end{tabular}

Údaje dokládají rozdíly v intenzitě citovanosti klíčových časopisů. Na jedné straně stojí časopis Pedagogika, který má výrazně nejvyšší citovanost v rámci českých časopisů. Na druhé straně jsou ostatní tři klíčové časopisy s nižší citovaností ve srovnání s Pedagogikou (viz k tomu diskusi v části 4).

\subsection{Rozsah citací v klíčových časopisech}

K charakteristice klíčových časopisů lze doplnit ještě zjištění o tom, jaký je rozsah citovaných publikací (tj. všech bibliografických údajů uváděných autory u jednotlivých statí). V tomto ukazateli se klíčové časopisy dosti shodují:

Pedagogika - v průměru 27 citací na jednu stat'; Pedagogická orientace 31 citací, Studia paedagogica - 29 citací, Orbis scholae - 34 citací. Většina statí má rozsah blízký k těmto průměrům, odlišují se pouze přehledové stati s vyššími počty citací (60 a více bibliografických údajů). 


\section{Diskuse}

Tato citačníanalýza dává podněty kněkolikerýmúvahám.Stručnějezdevyložím.

1. Může se jevit překvapující, že $\mathrm{v}$ daných pedagogických časopisech je značně vysoká převaha knižních citací nad časopiseckými citacemi (viz tabulka 1). Vzhledem $\mathrm{k}$ přisuzované významnosti akademických časopisů v české i mezinárodní pedagogické komunitě je to zvláštní. Avšak zdá se, že je to pro využívání informačních zdrojů v pedagogice příznačné:

- Nejen v zde popsané analýze, ale také v obdobných předchozích citačních analýzách byly shledány stejné poměry. Například Ježková (1995) zjistila v souboru citací ve 182 statích publikovaných v časopise Pedagogika (za období 1990-1994) toto rozložení: 64,4 \% knižních pramenů, 35,6 \% časopiseckých pramenů. Také již v dřívějším období (Průcha, 1975) v souboru 3252 citací v časopise Pedagogika (za roky 1970-1974) jsem zjistil shodné rozložení: 62,3\% knižní prameny, $37,7 \%$ časopisecké prameny. $Z$ toho by se dalo usuzovat na poměrně stabilní, na čase nezávislý vzorec využívání časopiseckých pramenů v české pedagogice.

- Když jsem porovnával toto zjištění s výsledky citačních analýz v jiných vědních oborech (technických a lékařských), ukázaly se zcela opačné poměry: Vysoká převaha časopiseckých pramenů (60-80\%) nad knižními prameny (viz data in Průcha, 1975).

Na základě těchto nálezů lze patrně tvrdit, že pedagogika je věda, v níž se informační zdroje (demonstrované v citacích) čerpají hlavně z neperiodických zdrojů a v menší míře z periodických zdrojů (časopisů). Naopak v přírodovědných, technických, lékařských oborech je tomu opačně. Je to snad důsledkem toho, že pedagogika na rozdíl např́iklad od fyziky či chemie je méně dynamickým oborem, kde se základní teorie a paradigmata nemění tak prudce jako $\mathrm{v}$ přírodních či technických oborech? A tedy že pro pedagogiku jsou nejnovější výsledky výzkumu publikované v časopisech méně závažné než informace v knižních publikacích? S tím by se asi dalo stěží souhlasit, avšak jaké jiné, věrohodnější vysvětlení je možno nabídnout?

2. Druhou diskusní záležitostí může být zjištění o výrazně vyšším podílu citovaných zahraničních časopisů (zhruba 70 \%) než českých časopisů (zhruba $30 \%$ ) vpedagogických statích klíčových časopisů.V tomto ohledu se situace 
oproti předchozím desetiletím změnila: $\mathrm{V} 70$. letech jsem zjistil mírně vyšší podíl zahraničních (cizojazyčných) pramenů nad československými (Průcha, 1975). Tehdy mezi zahraničními prameny vysoce převládaly publikace $v$ ruštině. Dnes je situace zcela odlišná, a to již od počátku 90. let, od kdy dominují anglicky psané informační zdroje, kdežto rusky psané publikace nejsou využívány skoro vůbec.

Celkově ovšem je intenzivní využívání zahraničních časopisů českými autory jistě pozitivním jevem. Dokládá to, s jak velkým zájmem se čeští pedagogové snaží vyhledávat a využívat nejnovější vědecké poznatky ze zahraničí a zprostředkovávat je do domácí profesní sféry. Jazyková vybavenost českých pedagogických výzkumníků a teoretiků pedagogiky se zřejmě natolik zdokonalila (na rozdíl od situace přetrvávající ještě na počátku 90. let), že práce se zahraničními publikacemi (především v angličtině) se již stala samozřejmostí.

3. Poslední záležitostí hodnou diskuse je samotný význam výrazu využívání informačních zdrojů, zvláště v konfrontaci se zjištěním o relativně nižší citovanosti časopisů ve srovnání s citovaností knižních publikací. Je totiž nutno vidět omezení citační analýzy: ona odráží pouze to, do jaké míry autoři uvádějí (někdy podle jiných než striktně objektivních kritérií) své zdroje v bibliografických seznamech doprovázejících jejich práce. Avšak tím se „využívání“ zdrojů nevyčerpává.

Hlavní způsob využívání publikovaných zdrojů (a tedy i našich čtyř klíčových časopisů) spočívá $\mathrm{v}$ tom, že pedagogičtí odborníci jsou nějak ovlivňováni tím, co si přečtou $\mathrm{v}$ publikovaných statích dalších kolegů. At' jde o pozitivní či negativní ovlivňování, vždy se jedná o určité sdílení informací, tedy o rozšiřování či rekonstruování individuální kognitivní vybavenosti uživatelů informačních zdrojů. Konkrétně tedy si lze představit, že když pedagogičtí výzkumníci, studenti, vzdělavatelé učitelů a jiní čtou nějakou stat' v časopise Pedagogická orientace či Orbis scholae, pak poznatky, které z četby získávají, mohou působit na jejich vědění. Následně se to může, ale nemusí projevovat tím, že když sami něco publikují, využívají k tomu získané poznatky a citují jejich zdroje.

To je ovšem záležitost, která se vymyká exaktnímu uchopení. Do hry vstupuje značný počet determinant, mezi nimi i faktický impakt (vliv, dosah, působnost) jednotlivých časopisů: Jestliže má Pedagogika náklad 
asi 600 výtisků, Pedagogická orientace asi 400 výtisků, Studia paedagogica a Orbis scholae asi 200-250 výtisků, je už z těchto počtů zřejmá limitovanost reálného impaktu těchto časopisů. I když zároveň je nutno vidět, že část čtenářů (ale jak početná je fakticky?) pročítá tyto časopisy (ale s jakou pravidelností?) v knihovnách, studovnách apod. Kromě toho je zde ještě jedna důležitá okolnost: Mnoho odborníků (i v pedagogice) vyhledává a využívá informace $\mathrm{z}$ elektronických médií, nikoliv jen (či dokonce nikoliv prioritně?) z tištěných médií. Jak časté a intenzivní využívání elektronických zdrojů ve srovnání s klasickými zdroji fakticky je, o tom lze zatím jen spekulovat. Je to zřejmě také velmi odlišné individuálně.

Skepse vůči pedagogickým časopisům by tedy nebyla na místě. I když o reálném využívání časopisů ve výše uvedeném širším smyslu zatím mnoho nevíme. Bez časopisů - zejména těch čtyř klíčových - by se česká pedagogická věda (teorie a zvláště výzkum) bezpochyby nemohla rozvíjet tak úspěšně jako se to děje v posledních letech.

\section{Literatura}

Ježková, V. (1995). Využívání informací v českém pedagogickém výzkumu. In Český pedagogický výzkum v současných společenských podmínkách. Sborník z III. mezinárodní konference (s. 42-46). Brno: Česká asociace pedagogického výzkumu.

Mareš, J. (2010). Publikování výsledků výzkumu a vykazování výsledků výzkumu na českých vysokých školách. Pedagogika, 60(3-4), 342-345.

Mareš, J., \& Honsnejmanová, J. (2011). Diskuse o pedagogických časopisech v České republice. Pedagogická orientace, 21(1), 104-113.

Průcha, J. (1975). Využívání informací v českém pedagogickém výzkumu. Pedagogika, 25(4), 461-477.

Průcha, J. (2010). Informační zdroje českých pedagogů. In Kam směřuje současný pedagogický výzkum? Sborník př́spěvků XVIII. celostátní konference ČAPV. Liberec: ČAPV a Fakulta přírodovědně-humanitní a pedagogická TU. [CD-ROM]

\section{Autor}

Prof. PhDr. Jan Průcha, DrSc., nezávislý expert, Varnsdorfská 333, 19000 Praha 9, e-mail: janprucha@volny.cz 